\title{
Study on Supply Chain Management Based on Social Responsibility
}

\author{
Maohua Li \\ Faculty of Economics and Social Sciences, Szent István \\ University \\ School of Business, Xi'an Siyuan University \\ Gödöllö, Hungary \\ maohua.li@qq.com
}

\author{
Zéman Zoltán \\ Institute of Business Studies, Faculty of Economics and \\ Social Sciences, Szent István University \\ Gödöllö, Hungary \\ Zeman.Zoltan@gtk.szie.hu
}

\begin{abstract}
As the development of economy, many problems occurred, such as environmental problems, food safety, health insurance, etc. Besides, the supply chains are becoming more and more complicated and sometimes they are overlapped. This paper wants to build a new SCM model based on CSR to solve these problems. Through the method of introduction of CSR into SCM, this paper finally builds a new SCM model. This model concerns the supply chain as a circle for the first time. And in this model, all the roles in the supply chain are cooperators, and they should concern the wholesome interest.
\end{abstract}

\section{Keywords-CSR; SCM; Cooperation; Circle}

\section{INTRODUCTION}

As the development of economy, supply chain is more and more important. The vertically integrated corporation of the 20th century has been replaced by disaggregated global supply chains across many industries[1]. So supply chain management has been attracting more and more attention from the practical and the academic. And supply chain management is a critical aspect of conducting any business[2]. However, the sustainability of supply chain management is a core problem for present erratic economic environments. Thus sustainable supply chain management (SSCM) has received much consideration from corporate and academic over the past decade $^{3}$. Even some scholars have obtained several techniques and tools for SSCM. One of the techniques that can be used for sustainable supplier performance evaluation and selection is data envelopment analysis (DEA)[3]. However, Theory-building efforts in SSCM remain scarce, with the predominance of a few popular imported macro theories (resource-based view (RBV), stakeholder theory and institutional theory) having implications on the conceptualization of SSCM and the topics researched to date. More theoretical contributions can potentially emerge from the adoption of original methodologies, the investigation of under-explored aspects of SSCM and the testing of recently developed frameworks[4].

Corporate social responsibility (CSR) is emerging as a catalyst in socio economic development of the country. Due to the provisions of corporate social responsibility, it is evolving as a new tool of social development[5]. And corporate social responsibility (CSR) is a product of the post-World War II period[6]. Wirth, Herbert, et al (2016)use mining companies as research sample to explain the role of CSR. The main role of
CSR for mining companies is to ensure a responsible business venture to reduce potential risks arising from safety issues and a potential negative environmental footprint and to attract better employees and gain acceptance among local society[7].

This paper wants to renew the supply chain management model by the application of CSR. The application of CSR in SCM will ensure the sustainability of the SCM and concern more about the interests of the stakeholders.

\section{LITERATURE REVIEW}

\section{A. Research on CSR}

Corporate social responsibility (CSR) has been researched for several years and many research findings have been obtained. And many topics have been studied, such as the importance of CSR, the application of CSR, the evaluation of CSR, CSR in different industries and so on.

Carroll A B (1999) studies the detail of the evolution of the CSR definitions. There is an impressive history associated with the evolution of the concept and definition of corporate social responsibility (CSR) [8].

On the application of CSR, McGuire, J. B., Sundgren, A., \& Schneeweis (1998) uses the empirical method to study the relation between CSR and firm financial performance[9].

On the evaluation of CSR, Maohua Li and Zotan Zeman (2016) Takes Chinese agricultural enterprises as a sample to construct an evaluation framework to help judge the quality of social responsibility information disclosure (SRID) [10].

On the study of CSR in different regions or industries, Maignan, I., \& Ralston, D. A. (2002) compares the extent and content of businesses' communications about corporate social responsibility (CSR) in France, the Netherlands, the U.K., and the U.S. In particular, the study investigates the nature of CSR principles, processes, and stakeholder issues discussed in web pages. The results show that businesses in the four countries do not display the same eagerness to appear as socially responsible and employ diverse means to convey social responsibility images[11].

\section{B. Research on SCM}

Supply chain and supply chain management (SCM) have been studies for decades at home and abroad. And now days, there are abundant research results, such as supply chain 
management model, the function of SCM, the application of SCM, the industry researches of SCM and case study of SCM.

Handfield, R. B., \& Nichols, E. L. (1999) examine the existing research in an effort to understand the concept of "supply chain management." Various definitions of SCM and "supply chain" are reviewed, categorized, and synthesized[12]. Love, P. E., Irani, Z., \& Edwards, D. J. (2004) find that a seamless project supply chain management (SCM) model is proposed that integrates the design and production processes of construction projects[13].

\section{IMPORTANCE OF SCM BASED ON CSR}

\section{A. The partial overlap of supply chains}

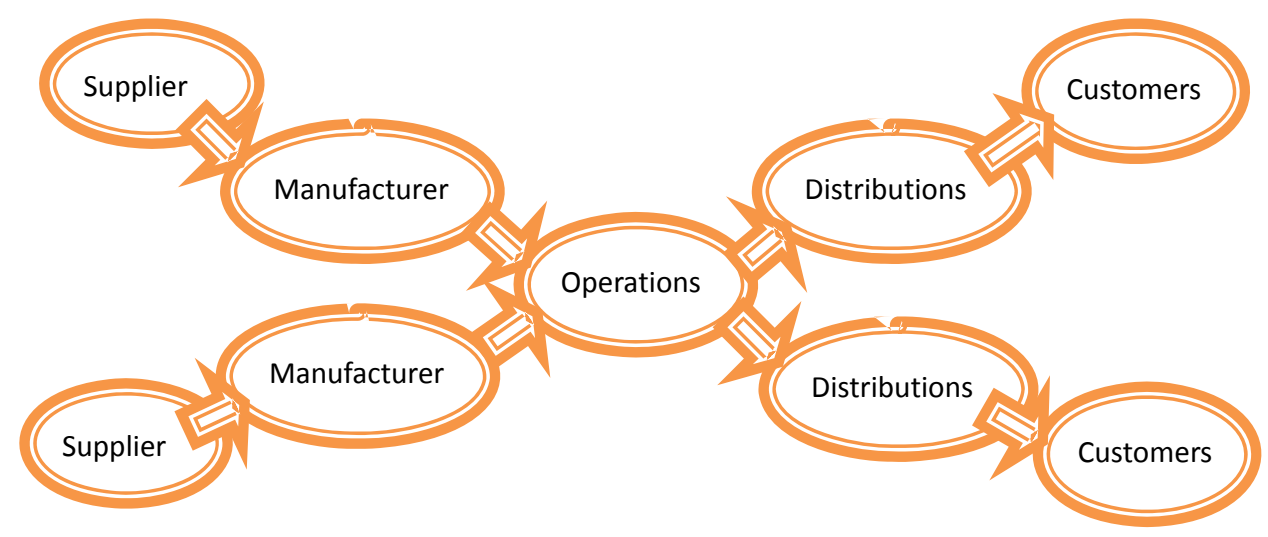

Fig. 1. The partial overlap of supply chains

In the past, supply chain is treated as a line, which contains supplier, manufacturer, operations, distributors and customers. The material raw will flow from the supplier to next manufacturer and finally to the customers. However, as the development of economy, the supply chains have been more and more complicated and some of them are overlapped. For example, in the Fig. 1, we can see that one operation has two manufacturers and in the real situation, there will be more than
2 manufacturers. At the same time, it has 2 distributions. In this case, if one of the links does not want to take its social responsibility to others, it will hurt all the interest of others and finally hurt the interest of itself. So in the so complicated supply chain system, corporate social responsibility is very important.

\section{B. The concerns of competition and profit}

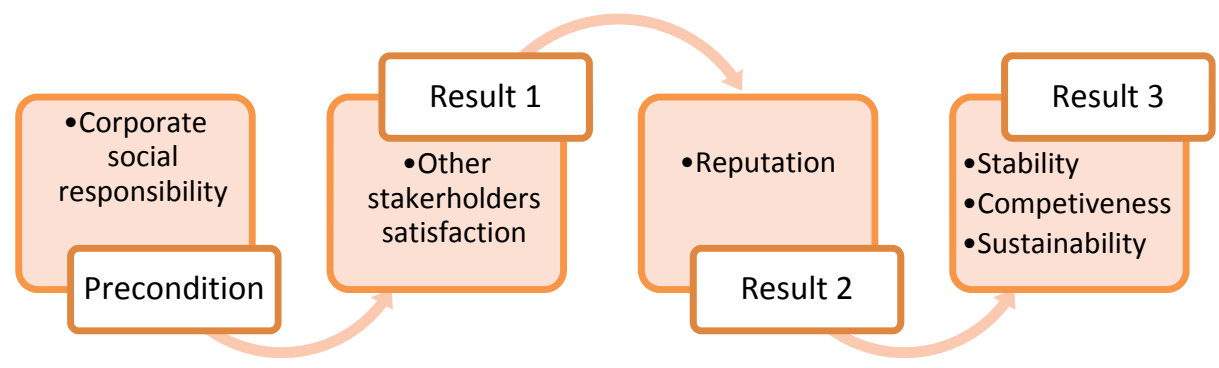

Fig. 2. The concerns of competition and profit based on CSR

In the traditional supply chain management, all the links only care about their own interests and care little about others. For instance, the manufacturer only cares about its only profit. It will try its best to cut the price of the supplier, and increase the price sold to the distributors.

In the SCM based on CSR, all the links in the supply chain will take their own social responsibility. During this situation, all the links in the supply chain will get other stakeholders satisfaction, and then their reputations will become better and better. At last, the links among them will become more and more stable, and the competiveness will become stranger and stranger. Finally, their profits will be more and more and the sustainability of the profits will be continual. 


\section{THEORETICAL SCM MODEL BASED ON CSR A. Traditional SCM model}

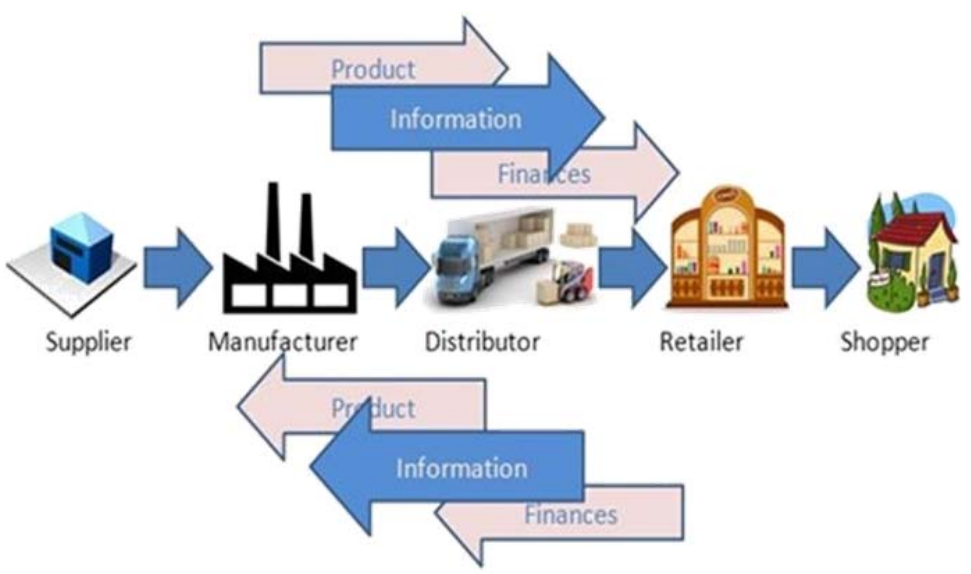

Fig. 3. Traditional SCM model ${ }^{1}$

In the traditional supply chain management model which is shown in Fig. 3, the total supply chain is like a line including supplier, manufacturer, distributor, retailer and shopper. They treat one another as competitors and profit sharers. In the traditional model, the total of the value added is determined once the retailing price is fixed, so what they can do to increase their own profit is do cut the price of suppliers and increase the price sold to the their customers.

\section{B. SCM model based on CSR}

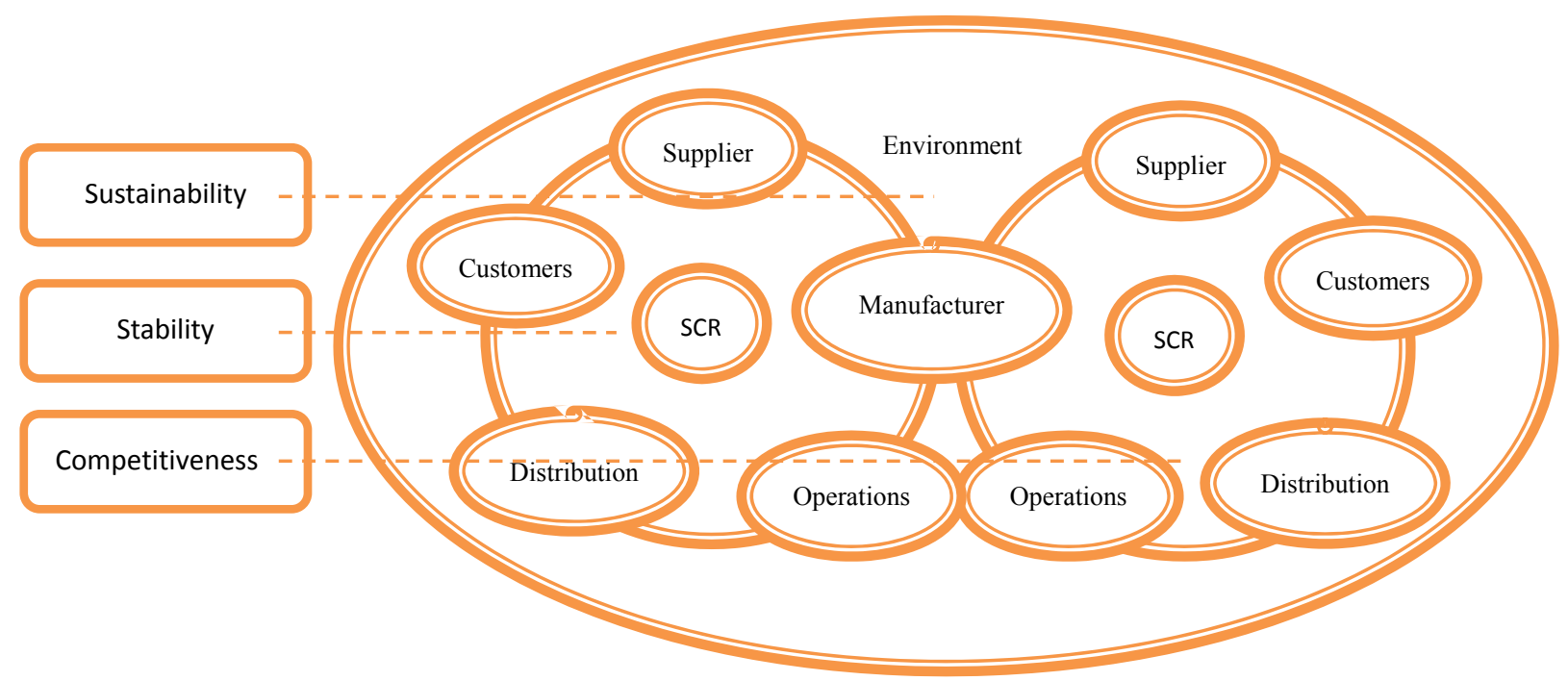

Fig. 4. SCM model based on CSR

As shown in the Fig. 4, if all the links in the supply chain take their own responsibilities to others. In the internal of the supply chain, the link will be more and more stable, and the cash flow and value flow will be more stable too. And all the links will get stable profit. That is the first word we can get under the situation of CSR. Compared with other supply chain or chains, it will get more and more competitiveness (as shown in the Fig. 4, they have something in overlap). This is the second word we can get under the corporate social responsibility.
Nowadays, as the development of economy, people pay more and more attention on the life quality and the environment where they are living. So as the main partners of the market, all the companies should take their social responsibility to the public interest, other stakeholders' interest, and the environment. If all the links take their responsibility to the environment, all the stakeholders will have sustainable surroundings to live on. This is the third word we can get under the corporate social responsibility.

\footnotetext{
${ }^{1}$ Sourcing: https://www.tutorialspoint.com/supply_chain_management/supply_chain_management_introduction.htm
} 


\section{The Significant Changes From Traditional SCM to SCM MODEL BASED ON CSR}

\section{A. From line to circle}

In the traditional supply chain in Fig. 3, the supply chain is a straight line from supplier to the shopper. However, in the SCM model based on CSR, the supply chain is a circle which contains supplier, manufacturer, operations, distributions and customers.

\section{B. From competition to cooperation}

In the traditional model, all the links treat one another as their competitors. And in the SCM based on CSR, all the links are cooperators. They will cooperate with one another to increase the total interest of all the stakeholders, to better the quality of the environment and to improve the life quality.

\section{From individual to wholesome}

In the traditional model, all the links only think they are individual, and they will they will think about their own interest and care nothing for the public and other stakeholders' interests. However, in the SCM model based on CSR, all the links will treat them as a wholesome, and they should care all the interest related to the links.

\section{From customer to supplier}

In the traditional model, the supply from the supplier to the customer will be over at last. But in the new model based on CSR, the link will be circled because of the CSR and circle economy. In the new model, all the customers will take their social responsibility to the environment and think more about the circle economy, and all the waste will be classified and resupplied to the new supplier. In this case, a circle will start.

\section{CONCLUSION AND DISCUSSION}

This paper wants to build a new SCM model based on CSR to solve some problems caused by the traditional SCM, such as they only care about their own interest, they pay on intention to the environmental problems etc.

According to the new SCM model based on CSR, all the links will cooperate as a wholesome to care about the whole interests of public, other stakeholders and environment. And in this situation, the link will become a circle from the straight line. All the links will be cooperators not competitors, and they will get more stable profit internal the circle and get more competitive outside the circle. At last, the whole society will get more and more sustainable because of the circle economy based on CSR.
However, there are still many problems that we should concern about. First, there is no empirical research to support this study, and fortunately, the data is under collection. Second, more detail should be considered in the empirical research, so when the author is doing the empirical research, all these detail will be reconsidered and modified.

\section{ACKNOWLEDGMENTS}

This work is sponsored by China Scholarship Council.

\section{REFERENCE}

[1] Kim, Y. H., \& Davis, G. F. (2016). Challenges for global supply chain sustainability: Evidence from conflict minerals reports. Academy of Management Journal, 59(6), 1896-1916.

[2] Lu, L. X., \& Swaminathan, J. M. (2015). Supply chain management.

[3] Azadi, M., Jafarian, M., Saen, R. F., \& Mirhedayatian, S. M. (2015). A new fuzzy DEA model for evaluation of efficiency and effectiveness of suppliers in sustainable supply chain management context. Computers \& Operations Research, 54, 274-285.

[4] Touboulic, A., \& Walker, H. (2015). Theories in sustainable supply chain management: a structured literature review. International Journal of Physical Distribution \& Logistics Management, 45(1/2), 16-42.

[5] Singh, B. J. R. (2016). Corporate social responsibility in India. International Journal of Higher Education Research \& Development, $1(1)$.

[6] Carroll, A. B. (2015). Corporate social responsibility. Organizational Dynamics, 44(2), 87-96.

[7] Wirth, H., Kulczycka, J., Hausner, J., \& Koński, M. (2016). Corporate Social Responsibility: Communication about social and environmental disclosure by large and small copper mining companies. Resources Policy, 49, 53-60.

[8] Carroll, A. B. (1999). Corporate social responsibility: Evolution of a definitional construct. Business \& society, 38(3), 268-295.

[9] McGuire, J. B., Sundgren, A., \& Schneeweis, T. (1988). Corporate social responsibility and firm financial performance. Academy of management Journal, 31(4), 854-872.

[10] Li, M., \& Zéman, Z. (2016). Study on the SRID evaluation framework of agricultural enterprises in China. Visegrad journal on bioeconomy and sustainable development, 5(1), 36-40.

[11] Maignan, I., \& Ralston, D. A. (2002). Corporate social responsibility in Europe and the US: Insights from businesses' self-presentations. Journal of International Business Studies, 33(3), 497-514.

[12] Mentzer, J. T., DeWitt, W., Keebler, J. S., Min, S., Nix, N. W., Smith, C. D., \& Zacharia, Z. G. (2001). Defining supply chain management. Journal of Business logistics, 22(2), 1-25.

[13] Love, P. E., Irani, Z., \& Edwards, D. J. (2004). A seamless supply chain management model for construction. Supply chain management: an international journal, 9(1), 43-56. 